\title{
Speciation of Arsenic Across Water-Sediment Interface of Falgu River
}

\author{
${ }^{1}$ Rajeeva Ranjan, ${ }^{1}$ Rekha Rani, ${ }^{2}$ Ashay Bavishi, \\ ${ }^{1}$ Shivadhar Sharma and ${ }^{2}$ Madhusudan Choudhary \\ ${ }^{1}$ Department of Chemistry, Magadh University, Bodh-Gaya, 824234, Bihar, India \\ ${ }^{2}$ Department of Biological Sciences, Sam Houston State University, Huntsville, Texas, 77341, USA
}

Received 2012-09-10, Revised 2012-09-30; Accepted 2012-12-31

\begin{abstract}
Two predominant species of arsenic compounds, As(III) and As(V), are found in soils and natural water and they have been classified as carcinogens. The focus of the present study was to examine the speciation of Arsenic (As) across the water-sediment interface at the confluence of drainage for Gaya city and the Falgu River. Gas Chromatography (GC) coupled to Inductively Coupled Plasma Mass Spectrometry (ICP-MS) was used to analyze the organic arsenic species while the inorganic arsenic species, As(III) and As(V), were analyzed by Anion Exchange Chromatography (AEC) coupled with Inductively Coupled Plasma Mass Spectrometry (ICP-MS). The determination of total arsenic load was carried out by colorimetric method using silver diethyldithiocarbamate and was measured at $535 \mathrm{~nm}$. Results revealed that the waters contained Monomethylarsine (MMA), Dimethylarsine (DMA), Trimethylarsine (TMA), As(III) as Arsenite $\left(\mathrm{AsO}_{3}{ }^{-3}\right)$ and $\mathrm{As}(\mathrm{V})$ as Arsenate $\left(\mathrm{AsO}_{4}{ }^{-3}\right)$. However, the methylated species were found in much higher concentrations in pore water from the sediment as compared to in the free water. The high levels of arsenic compounds found at the drainage sites pose a threat to human health and as such should be monitored and remediated promptly by the local and state governments.
\end{abstract}

Keywords: Arsenic, Arsine, Gaya, Geochemical Cycle, Methylated Arsenic, Speciation

\section{INTRODUCTION}

Arsenic is a metalloid, which exists broadly in two different forms and they are found in many different environments such as soil, fresh water, seawater, estuaries and sewage (Thayer, 2002; Dopp et al., 2004; Craig, 2003). Since arsenic occurs naturally in rocks and also produced by industrial mining and agricultural practices, it can leak out and pollute bodies of water including lakes and rivers (Melamed, 2005). The two main forms of arsenic present in the environment are $\mathrm{As}(\mathrm{III})$ and $\mathrm{As}(\mathrm{V})$, both of which are carcinogens causing skin, kidney, bladder and lung cancer. Furthermore, both of these compounds are toxic as they can modify proteins and inhibit enzymes involving oxidative phosphorylation and energy transfer (Ehrlich, 1996). The extent of arsenic poisoning within an individual is strongly correlated to the amount of arsenic the individual has been exposed to or has ingested. As a result, both the European Union and World Health Organization (Sayato, 1989) allow a maximum arsenic concentration of $10 \mu \mathrm{g} \mathrm{L}^{-1}$ in water. However, many developing countries are struggling to establish a standard of even $50 \mu \mathrm{g} \mathrm{L}^{-1}$ and as such, it is of dire importance that the level and underlying mechanisms of arsenic pollution be understood.

Although concentrations of pollutants are important, in many cases these are not sufficient, as many of the substances generally exist in more than one form. As such, a description of the species distribution for such substances becomes an important aspect to describe the level of contamination. During some biological processes, arsenate $\left(\mathrm{AsO}_{4}^{-3}\right)$ is reduced to the lower valence state As(III) and then methylated microbiologically into monomethyl arsine, dimethyl arsine and trimethyl arsine, all of which can then be Corresponding Author: Madhusudan Choudhary, Department of Biological Sciences, Sam Houston State University, Huntsville, Texas 77341, USA Tel: (936) 294-4850 Fax: (936) 294-3940 
oxidized by air to form the less toxic dimethyl arsenic acid $\left(\left(\mathrm{CH}_{3}\right)_{2} \mathrm{HAsO}_{4}\right)$ (Melamed, 2005; Mandal and Suzuki, 2002; Belluck et al., 2003). As(III) species, however, are much more toxic than $\mathrm{As}(\mathrm{V})$, as methylation of As(III) increases its volatility and therefore the mobility of methylated arsenic increases within the biogeochemical cycle (Cummings et al., 1999; Zobrist et al., 2000; Yamamura et al., 2007; Duester et al., 2008). However, to date, the methylation of arsenic has not been given sufficient importance with regard to its widespread impact upon the environment. A better knowledge of the biogeochemical cycles of arsenic in an anthropogenic-modified-environment is crucial to limit its adverse effects on both the environment and people.

Gaya is a religious landmark in India that attracts people from all over the world who come to observe the ritual of the departed soul of their ancestors. In particular the Falgu River, which passes through Gaya, is believed to be sacred to many people, who bathe in the river or drink its water. As such this study aims to contribute to this knowledge by revealing the speciation of arsenic across a specific example, in this case the watersediment interface in the drainage sites between the Falgu River and Gaya city.

\section{MATERIALS AND METHODS}

\subsection{Site Information}

Water and sediment samples were collected before the monsoon in 2008 from five sites at which the drainage of the city Gaya met the Falgu River. These five sampling sites are shown in Fig. 1. Within Fig. 1, site 1, also known as Ghughari Tand, is the first drainage of the city that meets the river, site 2 lies near Vishnupad temple, site 3 lies near the Pita Maheshwar area, site 4 lies near the Gaya-Manpur Bridge and site 5 is located on the Gaya side of the railway that crosses the bridge. It is important to note that these sites were all located on the same side of the river.

\subsection{Sample Collection}

From each of the five sites the surface water was taken in one-liter, polythene bottles. These samples were then immediately acidified by $2 \mathrm{~N} \mathrm{HCl}$, filtered through Whatman filter paper grade 42 and subsequently stored in clean polythene bottles. A grab sampler fitted with a semi-permeable polyethersulphone bag was then used for the sampling of the sediments. One sample was taken from a depth of $0-5 \mathrm{~cm}$ and another from a depth of 7-12 $\mathrm{cm}$. Inside the sampler the sediment sample was squeezed, releasing the pore water which then crossed the semi-permeable, polymer membrane. Since the membrane was even impermeable to bacteria, the pore water was thus sterilized and then acidified properly and stored in clean polythene bottles.

\subsection{Sediment Analysis}

The arsenic speciation analysis of the surface water and pore water was carried out by Gas Chromatography (GC) coupled to Inductive Coupled Plasma Mass Spectrometry (ICP-MS).

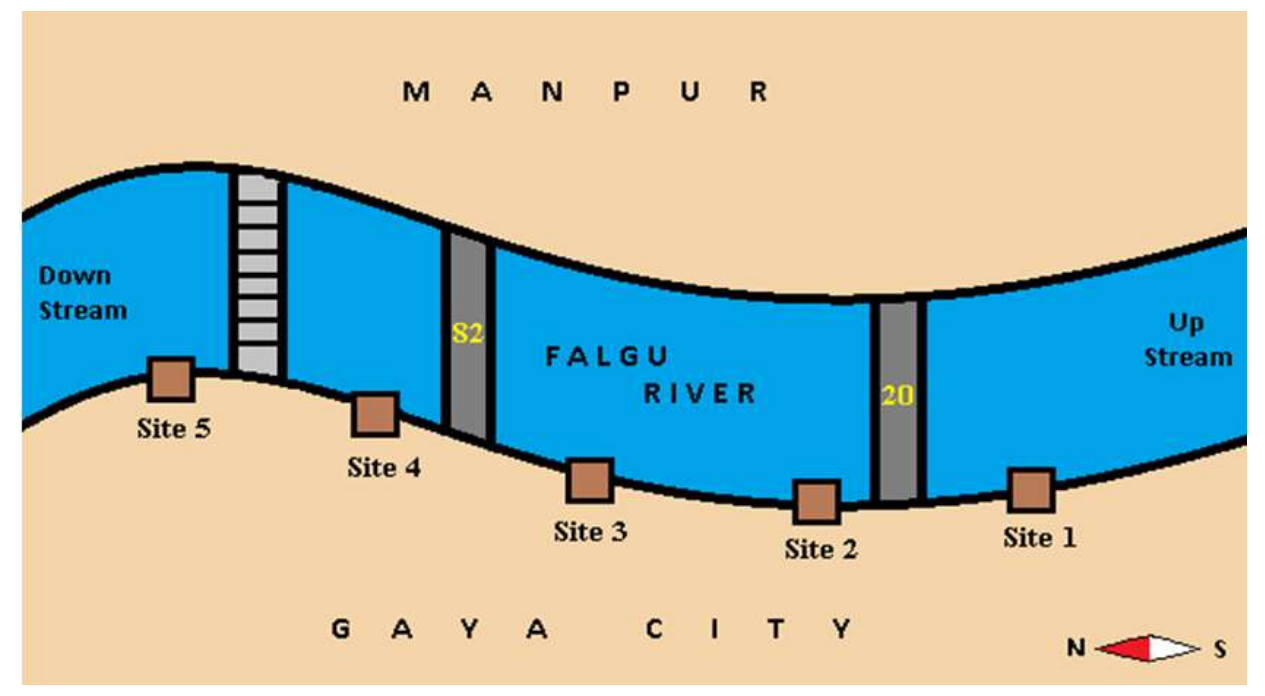

Fig. 1. Map of sampling sites 
The nonvolatile, methyl arsenic species were volatized and then cryotrapped in a glass tube. The separations and quantifications of the various species such as Monomethyl Arsine, (MMAs) Dimethyl Arsine (DMAs) and Trimethyl Arsine (TMAs) were carried out by heating the trap and gas chromatography column coupled to an ICP-MS as previously detailed by Feldmann (1997). The quantification of the organo-arsenic species, however, was done by measuring a multiorgano-arsenic standard containing $\left(\mathrm{CH}_{3}\right)$ As $(\mathrm{ONa})_{2},\left(\mathrm{CH}_{3}\right)_{2} \mathrm{AsO}(\mathrm{OH})$ and $\left(\mathrm{CH}_{3}\right)_{3} \mathrm{As}$.

To estimate As(III) and As(V), they were separated by Anion Exchange Chromatography (AEC) on a Dionex Model DX-300 with column Dionex Ion Pac AS11. The inorganic arsenic species As(III) and As(V), however, occur as neutral or negatively charged depending on the $\mathrm{pH}$. For the retention of arsenite $\left(\mathrm{pK}_{\mathrm{a}}=9.2\right)$ on anion exchangers it is absolutely necessary to work in a basic environment, else As(III) will elute within the void volume as previously described by Zbinden et al. (2000) and Chandrasekaran et al. (2002). Hence for isocratic elution, the optimized concentration of $\mathrm{NaOH}$ was used as the mobile phase to get a good baseline separation of the two species As(III) and As(V). For the quantization of the two species, the anion exchange chromatography (AEC) was coupled with Inductively Coupled Plasma Mass Spectrometry (ICPMS). The total arsenic determination was carried out by silver diethyl dithiocarbamate $\mathrm{S}$ $\|$

$\mathrm{Ag}-\mathrm{S}-\mathrm{C}-\mathrm{N}-\left(\mathrm{C}_{2} \mathrm{H}_{5}\right)_{2}$. At first the sample was treated with a $50 \% \mathrm{KMnO} 4$ solution to destroy the organic (methyl) binding arsenic portion in MMAs, DMAs and TMAs. Note that some As(III) may convert into As(V) from this process. Since As(III) is more efficient and nearly converted into $\mathrm{AsH} 3$, all the arsenic was first converted into $\mathrm{As}$ (III) in a prereduction step using $\mathrm{KI}+$ Ascorbic acid. This As(III) was then reduced into $\mathrm{AsH} 3$ by $\mathrm{NaBH} 4$ in an acid solution which was in a hydride generator (Gutzeit generation) and it was led into a scrubber containing glass wool impregnated with a lead acetate $\left(\left(\mathrm{CH}_{3} \mathrm{COO}\right)_{2} \mathrm{~Pb}\right)$ solution. From here it was placed into an absorber tube containing Silver Diethyldithiocarbamate (SDDC) solution in pyridine. As combined with SDDC salt it formed the soluble red complex, i.e., As $\left[\left(\mathrm{C}_{2} \mathrm{H}_{5}\right)_{2} \mathrm{~N} \text {. } \mathrm{CS}_{2}\right]_{3}$ which was measured at $535 \mathrm{~nm}$ against a reagent blank.

\section{RESULTS}

\subsection{Arsenic Species in Free Water}

The study reports the arsenic contamination in free water as shown in Table 1. It revealed that at all five sites the concentration of $\mathrm{As}(\mathrm{V})$ was significantly higher than that of $\mathrm{As}(\mathrm{III})$ (paired t-test, $\mathrm{p}$ value $=0.016$ ). As(III) comprised only $39-47 \%$ of total arsenic, while As(V) was found to comprise $52-61 \%$ of total arsenic. Furthermore, negligible amounts of organo-arsenoid species were found, indicative of very minimal microbial activity, however this issue was not fully investigated.

\subsection{Arsenic Species in Pore Water from Sediment}

The results that have been given in Table 2 reveal that across all five sites the pore water from sediment 0-5 cm contains $\sim 6 \mu \mathrm{g} \mathrm{L}^{-1}$ of As(III) and $\sim 0.4 \mu \mathrm{g} \mathrm{L}^{-1}$ of $\mathrm{As}(\mathrm{V})$. As such, the concentration of $\mathrm{As}(\mathrm{III})$ is significantly more (56-68\% of total arsenic) than As(V) (only $3-5 \%$ of total arsenic) (paired t-test, $\mathrm{p}$ value = 4.06E-6).

Moreover, the pore water contained all three methylated forms of arsenic with the greatest concentration being DMAs followed in concentration by MMAs and then TMAs, which were found in the least concentration at all five sites. Also at site 5 the concentration of $\mathrm{As}(\mathrm{III})$ and DMAs were found to be abnormally high.

Table 1. Concentration in $\mu \mathrm{g} / \mathrm{L}$ of the different species of arsenic in free water

\begin{tabular}{llllllr}
\hline Site No. & As (III) & \multicolumn{2}{c}{ As (V) } & \multicolumn{4}{l}{ MMAs } & DMAs TMAs & As $_{\text {total }}$ \\
\hline 1 & 0.890 & 1.32 & 0.10 & - & - & 2.280 \\
2 & 0.720 & 0.92 & 0.10 & - & - & 1.780 \\
3 & 0.780 & 0.98 & 0.20 & - & & 1.720 \\
4 & 0.750 & 0.91 & 0.10 & - & - & 1.600 \\
5 & 0.920 & 1.42 & - & - & - & 2.300 \\
Average & 0.812 & 1.11 & 0.10 & - & - & 1.940 \\
\pm SD & \pm 0.088 & \pm 0.24 & \pm 0.07 & - & - & \pm 0.329 \\
\hline
\end{tabular}

-: no significant amount detected

Table 2. Concentration in $\mu \mathrm{g} / \mathrm{L}$ of the different species of arsenic in pore water from sediment $0-5 \mathrm{~cm}$ deep

\begin{tabular}{lrllllr}
\hline Site No. & As (III) & As(V) & MMAs & DMAs & TMAs & $\mathrm{As}_{\text {total }}$ \\
\hline 1 & 5.42 & 0.430 & 0.82 & 2.790 & 0.230 & 8.800 \\
2 & 5.61 & 0.450 & 0.91 & 2.880 & 0.200 & 8.260 \\
3 & 5.53 & 0.410 & 0.78 & 2.830 & 0.200 & 9.810 \\
4 & 5.55 & 0.430 & 0.89 & 2.870 & 0.280 & 10.310 \\
5 & 8.34 & 0.400 & 0.95 & 4.460 & 0.300 & 14.500 \\
Average & 6.09 & 0.424 & 0.87 & 3.166 & 0.242 & 10.336 \\
\pm SD & \pm 1.25 & \pm 0.013 & \pm 0.07 & \pm 0.720 & \pm 0.046 & \pm 2.460 \\
\hline
\end{tabular}


Table 3. Concentration in $\mu \mathrm{g} / \mathrm{L}$ of the different species of arsenic in pore water from sediment $7-12 \mathrm{~cm}$ deep

\begin{tabular}{lcccccc}
\hline Site No. & As(III) & \multicolumn{1}{c}{ As(V) } & MMAs & DMAs & TMAs & $\mathrm{As}_{\text {total }}$ \\
\hline 1 & 5.93 & 0.12 & 1.890 & 5.320 & 0.290 & 13.580 \\
2 & 5.64 & 0.10 & 1.810 & 5.420 & 0.340 & 13.410 \\
3 & 5.72 & 0.12 & 1.920 & 5.380 & 0.310 & 13.450 \\
4 & 5.78 & 0.11 & 1.890 & 5.430 & 0.330 & 13.590 \\
5 & 6.63 & 0.10 & 1.980 & 6.490 & 0.310 & 15.690 \\
Average & 5.94 & 0.11 & 1.898 & 5.608 & 0.316 & 13.944 \\
\pm SD & \pm 0.40 & \pm 0.01 & \pm 0.060 & \pm 0.490 & \pm 0.020 & \pm 0.970 \\
\hline
\end{tabular}

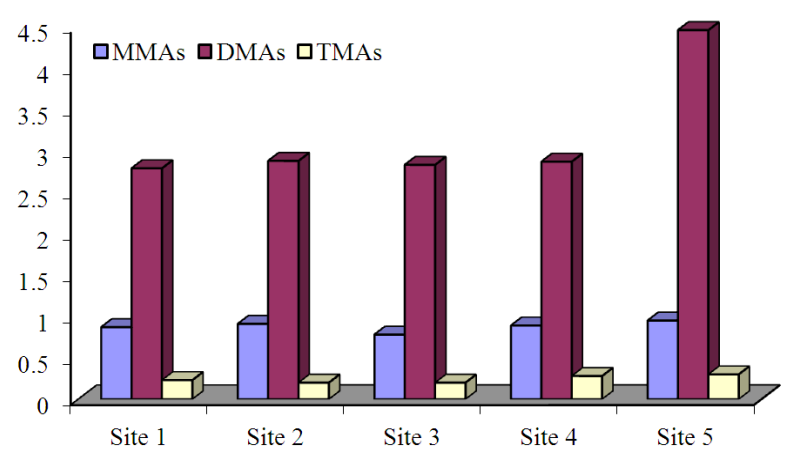

Fig. 2. Distribution of the MMAs, DMAs and TMA in pore water from sediment $0-5 \mathrm{~cm}$ deep

Table 3 displays the results of the analysis of pore water from sediment $7-12 \mathrm{~cm}$ deep. The data reveals that the concentration of $\mathrm{As}(\mathrm{V})$, as in terms of total arsenic, further decreases from $3-5 \%, 0-5 \mathrm{~cm}$ depth, to $0.63-0.88 \%$ $7-12 \mathrm{~cm}$ deep. Though the concentration $(\mu \mathrm{g} / \mathrm{L})$ of As(III) increases in respect to total arsenic, it decreases from 56$68 \%, 0-5 \mathrm{~cm}$ deep, to $42-44 \% 7-12 \mathrm{~cm}$ deep.

The concentration of MMAs increased at this depth while the concentration of DMAs was found to be the greatest with an average value $5.608 \mu \mathrm{g} \mathrm{\textrm {L } ^ { - 1 }}$. The concentration of TMAs also increased but this increase was very minor. The value of total arsenic concentration showed a significant increase.

\subsection{Distribution of As(III), As(V), Methylated Forms of Arsenic and Total As}

The distribution of the MMAs, DMAs and TMAs are shown in Fig. 2 and 3. The comparison of the concentrations of methylated arsenic in the pore water from sediment 0-5 cm deep (Fig. 2) to sediment 7-12 cm deep (Fig. 3) clearly reveal that the methylation of arsenic increases with increasing depth of sediment at all five sampling sites (paired t-test, $p$ value $=3.6 \mathrm{E}-9$ (MMAs), $\mathrm{p}$ value $=0.00013$ (DMAs) and $\mathrm{p}$ value $=$ 0.00535 (TMAs).

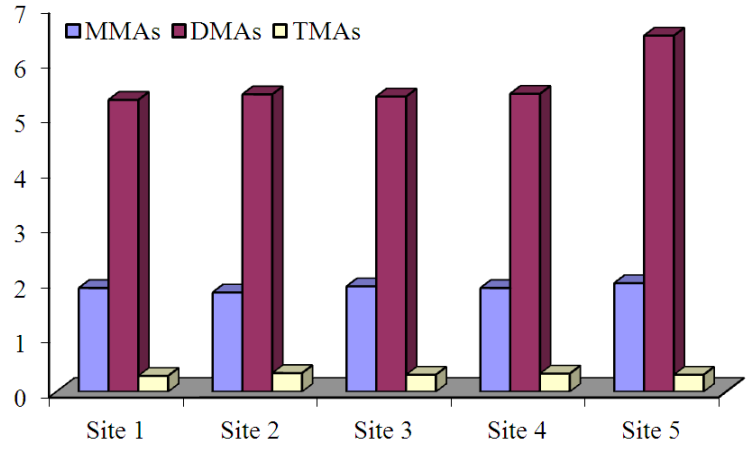

Fig. 3. Distribution of the MMAs, DMAs and TMA in pore water from sediment 7-12 cm deep

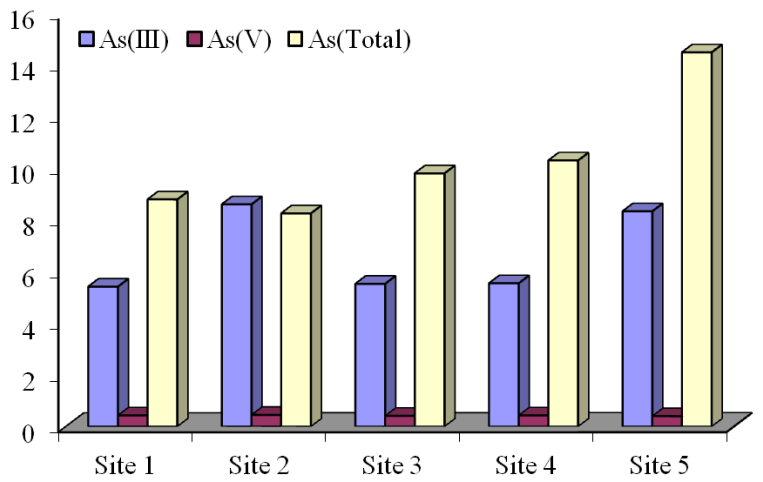

Fig. 4. Relative concentrations of $\mathrm{As}(\mathrm{III}), \mathrm{As}(\mathrm{V})$ and total arsenic in pore water from sediment $0-5 \mathrm{~cm}$ deep

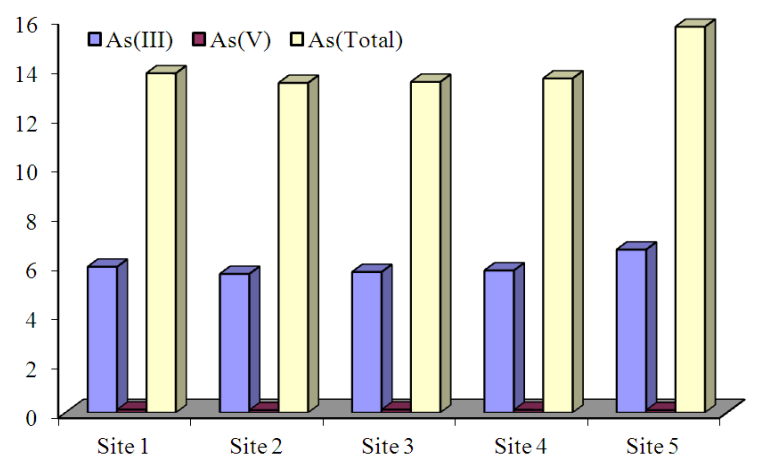

Fig. 5. Relative concentrations of $\mathrm{As}(\mathrm{III}), \mathrm{As}(\mathrm{V})$ and total arsenic in pore water from sediment $7-12 \mathrm{~cm}$ deep

The relative concentrations of $\mathrm{As}(\mathrm{III}), \mathrm{As}(\mathrm{V})$ and total arsenic in sediment $0-5 \mathrm{~cm}$ deep and sediment 7-12 $\mathrm{cm}$ deep have been shown by Fig. 4 and 5, respectively. Comparison between the information garnered at both depths shows that the concentration of As(III) dominates over $\mathrm{As}(\mathrm{V})$ as the depth increases. Moreover, the concentration of $\mathrm{As}(\mathrm{V})$ decreases with the 
increasing depth of sediment and at 7-12 $\mathrm{cm}$ deep becomes negligible $(0.11 \pm 0.01)$.

\section{DISCUSSION}

\subsection{As(III) and $A s(V)$ in Free and Pore Water}

The results from free water showed that As(V) was found in greater concentration as compared to As(III). This finding proposes that it may be due to the aerobic condition, prevailing within free water, that the $\mathrm{As}(\mathrm{V})$ species are more stable than the As(III) species. However, this higher concentration of $\mathrm{As}(\mathrm{V})$ may also be explained by an inefficient transformation of $\mathrm{As}(\mathrm{V})$ to As(III) due to a stronger binding of $\mathrm{As}(\mathrm{V})$ by microbial mat or other constituents present in the water, a concept paralleled by similar literature (Filella et al., 2002; 2007). Furthermore, the organo-arsenoid was found to be close to absent from the free water indicating very minimal to no significant microbial activity under the aerobic condition.

In contrast, the pore water from sediment both $0-5 \mathrm{~cm}$ deep and 7-12 cm deep, contained significantly greater concentrations of $\mathrm{As}(\mathrm{III})$ as compared to $\mathrm{As}(\mathrm{V})$, indicating that as soon as anaerobic conditions begin to develop, arsenite $\left(\mathrm{AsO}_{3}{ }^{-3}\right)$ is found in greater concentrations than arsenate. It is implicated that microbial species involving arsenic metabolism enhance such transformation processes (As(V) into As(III)) and support microbial driven biogeochemical cycle (Chandrasekaran et al., 2002). The cycle represents oxidation-reduction reactions involving $\mathrm{As}(\mathrm{V})$ and As(III) as well as methylated and thioarsenicals. Furthermore, $\mathrm{As}(\mathrm{V})$ reduction can occur in conjunction with sulfide oxidation and As(III) oxidation with nitrate reduction and therefore can be carried out in anaerobic environments. Moreover, the pore water contained all three methylated forms of arsenic making it clear that microbial activities start within the sediment under anaerobic conditions. Also at site 5 the concentration of As(III) and DMAs have been found to be abnormally high which may be attributed to the greater microbial activities occurring in the sediment at this site.

The concentration of all three methylated forms increased significantly, as much as two-fold at certain sites, within the pore water $7-12 \mathrm{~cm}$ deep once again indicative of the greater microbial activities going on under the more anaerobic conditions.

\subsection{Depth Dependence of Methylation of Arsenic}

The results revealed that the methylation of arsenic increases with increasing depth of sediment at all five sampling sites. This clearly indicates that methylation significantly influences both the translocation of arsenic in sediment and the transformation of arsenic into DMAs as it is much faster than that of MMAs and TMAs.

Furthermore, some microbes metabolize arsenic via methylation, demethylation, oxidation and reduction reactions to generate energy for their survival and biofilm production. Methylation reactions convert $\mathrm{As}(\mathrm{V})$ or As(III) into compounds such as MMA(V), MMA(III), DMA(V), (DMA(III) and trimethylarsine oxide as well as several volatile arsines, including monomethylarsine, dimethylarsine and trimethylarsine. Although many of the enzymes involved for such transformation remain unknown, a methyl transferase, ArsM, discovered from Rhodobacter sphaeroides confers resistance to arsenic and can generate trimethylarsine (Moore and Kaplan, 1992).

\subsection{Depth Dependence of As(III), As(V) and Total As}

As(III) siginificantly dominates over $\mathrm{As}(\mathrm{V})$ as the depth increases which may be attributed to increasing microbial activities that cause greater reduction of $\mathrm{As}(\mathrm{V})$ into As(III).

Furthermore, at 7-12 cm deep As(V) can be seen in negligible amounts which is probably a result of the greater adsorption of $\mathrm{As}(\mathrm{V})$ to $\mathrm{Fe}(\mathrm{III})$ and $\mathrm{Al}(\mathrm{III})$ oxide and hydroxide respectively which may have not passed into pore water due to their being insoluble. This also confirms the earlier reported result of As(III) being much less adsorptive on $\mathrm{Fe}(\mathrm{III})$ and $\mathrm{Al}(\mathrm{III})$ oxides, hydroxides and more mobile than As(V) (Smith et al., 1998; Bhumbla and Keefer, 1994).

\subsection{Biological Interplay of Arsenic}

Several microorganisms have been studied for the bioremediation of heavy metals and metalloids and their mechanisms are well understood. It is thought that As(V) reduction can be carried out in two distinct manners. One mechanism involves dissimilatory reduction of arsenate and was discovered in Sulfurospirillum arsenophilum (Stolz et al., 2006). It has also been identified in several Crenarchaeota and several other species of bacteria, in which As(V) serves as a terminal electron acceptor (Stolz et al., 2006). These organisms are resourceful as they can use both organic and inorganic electron donors as well as other electron acceptors. Another mechanism of $\mathrm{As}(\mathrm{V})$ reduction involves ArsC and resistance genes. A diverse group of species belonging to Archaea, Eubacteria, yeasts and protists have been found to possess resistance genes located on plasmids and/or 
chromosomes (Silver and Phung, 2005). Although there are different mechanisms by which such resistance genes operate, it has been found that in E. Coli, Staphylococcus and yeast possess three components to their complex reduction system-though to have evolved in these organisms via convergent evolution (Silver and Phung, 2005). These three components include: The arsenate reductase ArsC, related to tyrosine phosphatephosphatases; ArsB, the arsenite-specific efflux pump; and a source of reducing equivalents, thioredoxin or glutaredoxin (Kaur and Rosen, 1992; Stolz et al., 2006).

\section{CONCLUSION}

In aerobic conditions the biomethylating bacteria are not very active. However, their activities increase significantly under anaerobic conditions and hence biomethylation of arsenic occurs mainly in sediment. Furthermore, the biomethylation of arsenic also increases with the increasing depth of sediment and thus the greater the methylation of arsenic the greater its translocation within the sediment. The transformation of arsenic into DMAs is much faster than MMAs and TMAs. The end product of biomethylation, arsenobetaine $\left(\mathrm{C}_{5} \mathrm{H}_{11} \mathrm{AsO}_{2}\right)$, has not been found even in trace amounts during this study. Hence, after the formation of dimethyl arsenic, methylation slows down even more. As(III) is less adsorptive and more mobile in deeper sediment layers as compared to $\mathrm{As}(\mathrm{V})$.

In every sample of free (surface) water and pore water from sediment, the concentration of total arsenic is greater than the maximum permitted value by both the World Health Organization (Sayato, 1989) and the European Union i.e., $10 \mu \mathrm{g} \mathrm{L}^{-1}$. These measures have been placed in light of the epidemiological evidence to support the carcinogenic nature of the ingested arsenic and its connection with liver, lungs and kidney diseases and other dermal effects (Feeney and Kounaves, 2000). Considering this, in the pore water from sediment 7-12 $\mathrm{cm}$ deep, the concentration of arsenic is much greater than the acceptable concentration which makes it of the utmost concern because this load of arsenic will subsequently release into river water making it toxic for domestic use. It is suggested that thermal, optical and $\mathrm{pH}$ biosensors should be used to regularly monitor the level of these arsenic species. It will be interesting to examine if these sites correspond to the microbial species abundance that actively participates in the arsenate reduction and methylation processes. These investigations are currently in progress. Hence it is strongly recommended that the municipal, local and state authorities take it seriously to treat the drainage properly before it passes on into the river. The extent of arsenic poisoning within an individual is strongly correlated to the amount of arsenic the individual in question has been exposed to or has ingested. Therefore, any action taken to solve the rising problem of arsenic contamination in the Falgu River should be done promptly and efficiently as to reduce the impact of the adverse health effects arsenic imposes.

\section{ACKNOWLEDGMENT}

The researchers are thankful to Dr. Jagdish Sharma, Bhabha Atomic Research Centre, Mumbai, India for carrying out GC/ICP-MS and AEC/ICP-MS.

\section{REFERENCES}

Belluck, D.A., S.L. Benjamin, P. Baveye, J. Sampson and B. Johnson, 2003. Widespread arsenic contamination of soils in residential areas and public spaces: An emerging regulatory or medical crisis? Int. J. Toxicol., 22: 109-128. DOI: 10.1080/10915810305087

Bhumbla, D.K. and R.F. Keefer, 1994. Arsenic in the environment: Cycling and characterization. 1st Edn., John Wiley and Sons, New York, ISBN-10: 0471579297, pp: 430.

Chandrasekaran, K., D. Karunasagar and J. Arunachalam, 2002. Determination of inorganic arsenic species in water samples by HPLC-ICPMS. IANCAS, 1: 55-55.

Craig, P.J., 2003. Organometallic Compounds in the Environment. 2nd Edn., John Wiley and Sons Ltd, New York, ISBN-10: 0471899933, pp: 415.

Cummings, D.E., F. Caccavo Jr., S. Fendorf and F.R. Rosenzweig, 1999. Arsenic mobilization by the dissimilatory $\mathrm{Fe}(\mathrm{III})$-reducing bacterium Shewanella alga BrY. Environ. Sci. Technol., 33: 723-729. DOI: $10.1021 / \mathrm{es} 980541 \mathrm{c}$

Dopp, E., L.M. Hartmann, A.M. Florea, A.W. Rettenmeier and A.V. Hirner, 2004. Environmental distribution, analysis and toxicity of organometal(loid) compounds. Critical Rev. Toxicol., 34: 301-333.

Duester, L., J.P.M. Vink and A.V. Hirner, 2008. Methylantimony and -arsenic species in sediment pore water tested with the sediment or fauna incubation experiment. Environ. Sci. Technol., 42: 5866-5871. DOI: $10.1021 / \mathrm{es} 800272 \mathrm{~h}$ 
Ehrlich, H.L., 1996. Geomicrobiology. 3rd Edn., Marcel Dekker, New York.

Feeney, R. and S.P. Kounaves, 2000. On-site analysis of arsenic in groundwater using a microfabricated gold ultramicroelectrode array. Anal. Chem., 72: 22222228. DOI: $10.1021 /$ ac991185z

Feldmann, J., 1997. Summary of a calibration method for the determination of volatile metal(loid) compounds in environmental gas samples by using gas chromatography-inductively coupled plasma mass spectrometry. J. Ana. Atomic Spectrometry, 12: 1069-1076. DOI: 10.1039/A701264K

Filella, M., N. Belzile and M.C. Lett, 2007. Antimony in the environment: A review focused on natural waters. III. Microbiota relevant interactions. EarthSci. Rev., 80: 195-217. DOI: 10.1016/j.earscirev.2006.09.003

Filella, M., N. Belzile and Y.W. Chen, 2002. Antimony in the environment: A review focused on natural waters: II. Relevant solution chemistry. Earth-Sci. Rev., 59: 265-285. DOI: 10.1016/S00128252(02)00089-2

Kaur, P. and B.P. Rosen, 1992. Plasmid-encoded resistance to arsenic and antimony. Plasmid, 27: 2940. DOI: 10.1016/0147-619X(92)90004-T

Mandal, B.K. and K.T. Suzuki, 2002. Arsenic round the world: A review. Talanta, 58: 201-235. DOI: 10.1016/S0039-9140(02)00268-0

Melamed, D., 2005. Monitoring arsenic in the environment: A review of science and technologies with the potential for field measurements. Analytica Chim. Acta, 532: 1-13. DOI: 10.1016/j.aca.2004.10.047

Moore, M. and S. Kaplan, 1992. Identification of intrinsic high-level resistance to rare-earth oxides and oxyanions in members of the class Proteobacteria: characterization of tellurite, selenite and rhodium sesquioxide reduction in Rhodobacter sphaeroides. J. Bacteriol., 174: 1505-1514.
Sayato, Y., 1989. WHO guidelines for drinking water quality. Eisei Kagaku, 35: 307-312.

Silver, S. and L.T. Phung, 2005. Genes and enzymes involved in bacterial oxidation and reduction of inorganic arsenic. Applied Environ. Microbiol., 71: 599-608. DOI: 10.1128/AEM.71.2.599-608.2005

Smith, E., R. Naidu and A.M. Alston, 1998. Arsenic in the soil environment: A review. Adv. Agronomy, 64: 149-195. DOI: 10.1016/S0065-2113(08)60504-0

Stolz, J.F., P. Basu, J.M. Santini and R.S. Oremland, 2006. Arsenic and selenium in microbial metabolism. Ann. Rev. Microbiol., 60: 107-130. DOI: 10.1146/annurev.micro.60.080805.142053

Thayer, J.S., 2002. Review: Biological methylation of less-studied elements. Applied Organometallic Chem., 16: 677-691. DOI: 10.1002/aoc.375

Yamamura, S., M. Yamashita, N. Fujimoto, M. Kuroda and M. Kashiwa et al., 2007. Bacillus selenatarsenatis sp. nov., a selenate- and arsenatereducing bacterium isolated from the effluent drain of a glass-manufacturing plant. Int. J. Systematic Evolut. Microbiol., 57: 1060-1064. DOI: 10.1099/ijs.0.64667-0

Zbinden, P., D. Andrey and C. Blake, 2000. A routine ion chromatography ICP-MS method for the analysis of arsenic species applicable in the food industry. J. Analytical Atomic Spectrometry, 21: 205-213.

Zobrist, J., P.R. Dowdle, J.A. Davis and R.S. Oremland, 2000. Mobilization of arsenite by dissimilatory reduction of adsorbed arsenate. Environ. Sci. Technol., 34: 4747-4753. DOI: 10.1021/es001068h 